\title{
MANAJEMEN SUMBER DAYA INSANI
}

\section{Sukarno L. Hasyim \\ Jurusan Syariah STAIM Nglawak, Kertosono, Nganjuk}

Email : sukarno165@gmail.com

\begin{abstract}
Abstrak
Pada dasarnya setiap organisasi tidak akan lepas dari keberadaan sumber daya insani yang dapat membantu melaksanakan serangkaizin aktivitas dalam pencapaian tujuan organisasi. Untuk itu diperlukan pula peran aktif manajer dalam memahami dan mengelola orang-orang yang ada dalam organisasi. Pengelolaan sumber daya insani harus dilakukan secara efektif dan efisien. Manajemen Sumber Daya Insani (MSDI) ini tidak saja mengandalkan pada fungsi manajemen seperti perencanaan, pengorganisasian, pengarahan dan pengendalian, namun pada implementasinya, mengandalkan pada fungsi operasional manajemen SDM seperti rekrutmen, seleksi, penilaian prestasi, pelatihan dan pengembangan, serta praktek pemberian kompensasi.
\end{abstract}

Kata kunci: manajemen, fungsi, organisasi, keberadaan

\section{Abstract}

Basically, each organization will not be separated from the existence of human resources that can help carry out a series of activities in achieving organizational goals. This requires an active role of managers in understanding and managing people in the organization. Human resource management must be carried out effectively and efficiently. This Islamic Human Resource Management (MSDI) not only relies on management functions such as planning, organizing, directing and controlling, but in its implementation, relying on operational HR management functions such as recruitment, selection, performance appraisal, training and development, and the practice of compensation.

Keywords: management, function, organization, existence

\section{PENDAHULUAN}

Manajemen Sumber Daya Insani yang disingkat MSDI adalah suatu ilmu atau cara mengatur hubungan dan peranan sumber daya (tenaga kerja) yang dimiliki oleh individu secara efektif dan efisien serta dapat digunakan secara maksimal sehingga tercapai tujuan (goal) bersama perusahaan, karyawan dan masyarakat menjadi maksimal.

Sumber daya insani merupakan kekuatan terbesar dalam pengolahan seluruh sumber daya yang ada di muka bumi. Manusia 
diciptakan oleh Allah SWT sebagai khalifah di bumi untuk mengelola bumi dan sumber daya yang ada di dalamnya demi kesejahteraan manusia sendiri, makhluk dan seluruh alam semesta, karena pada dasarnya seluruh ciptaan Allah untuk kemaslahatan umat manusia. Hal ini telah ditegaskan oleh Allah dalam Al-Qur'an Surat Al-Jatsiyah ayat 13 :

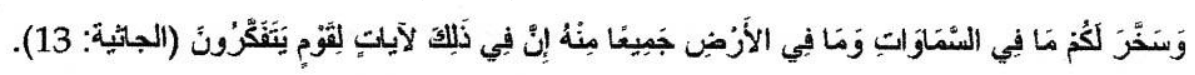

"Dan Dia telah menundukkan untukmu apa yang di langit dan apa yang di bumi semuanya, (sebagai rahmat) daripada-Nya. Sesungguhnya pada yang demikian itu benar-benar terdapat tanda-tanda (kekuasaan Allah) bagi kaum yang berfikir".

MSDI didasari pada suatu konsep bahwa setiap karyawan adalah manusia bukan mesin dan bukan semata menjadi sumber daya bisnis. Kajian MSDI menggabungkan beberapa bidang ilmu seperti psikologi, sosiologi, dan lain sebagainya.

Unsur MSDI adalah manusia. MSDI jugs menyangkut desain dan implementasi sistem perencanaan, penyusunan karyawan, pengembangan karyawan, pengelolaan karier, evaluasi kinerja, kompensasi karyawan dan hubungan ketenagakerjaan yang baik. MSDI melibatkan semua keputusan dan praktek manajemen yang mempengaruhi secara langsung sumber daya insaninya.

\section{METODE PENELITIAN}

Penelitian ini jenisnya kualitatif. Menurut Kirt dan Miller bahwa penelitian kualitatif adalah tradisi tertentu dalam ilmu pengetahuan sosial yang secara fundamental tergantung pada pengamatan terhadap manusia dalam kawasannya sendiri dan berhubungan dengan orang-orang tersebut dalam bahasannya dan dalam peristilahannya. ${ }^{1}$

Penyusun atau peneliti menggunakan jenis penelitian literal (library research) yaitu suatu penelitian dengan cara menuliskan, mengklarifikasikan dan menjadikan data yang diperoleh dari berbagai sumber tertulis. Kemudian menganalisis sumber-sumber literatur yang berkaitan dengan materi dan difokuskan pada penelaahan masalah yang dibahas. $^{2}$

${ }^{1}$ Maman Rachman, Strategi dan Langkah-langkah Penelitian. (Semarang: IKIP Semarang Perss, 1999), 20.

${ }^{2}$ Noeng Muhajir, Motede Penelitian Kualitatif, Edisi II, cet. Ke-8 (Yogyakarta: Rake Sarasin, 1983);:43 


\section{PEMBAHASAN}

MSDI diperlukan untuk meningkatkan efektivitas sumber daya insani dalam organisasi. Tujuannya adalah memberikan kepada organisasi satuan kerja yang efektif. Untuk mencapai tujuan ini, studi tentang manajemen personalia akan menunjukkan bagaimana seharusnya perusahaan mendapatkan, mengembangkan, menggunakan, mengevaluasi, dan memelihara karyawan dalam jumlah (kuantitas) dan tipe (kualitas) yang tepat.

MSDI adalah suatu proses menangani berbagai masalah pada ruang lingkup karyawan, pegawai, buruh, manajer dan tenaga kerja lainnya untuk dapat menunjang aktivitas organisasi atau perusahaan demi mencapai tujuan yang telah ditentukan. Bagian atau unit yang biasanya mengurusi SDI adalah Departemen Sumber Daya Insani atau dalam bahasa inggris disebut HRD atau human resource department. MSDI adalah ilmu dan seni mengatur hubungan dan peranan tenaga kerja agar efektif dan efisien membantu terwujudnya tujuan perusahaan, karyawan dan masyarakat. ${ }^{3}$

Menurut Mathis dan Jackson sumber daya insani adalah rancangan sistem-sistem formal dalam sebuah organisasi untuk memastikan penggunaan bakat manusia secara efektif dan efisien guna mencapai tujuan organisasi. Hal ini juga terungkap dalam Al-Qur'an yang meneran.gkan bahwa manusia merupakan makhluk yang tercipta sempurna dan memiliki banyak potensi dalam dirinya.

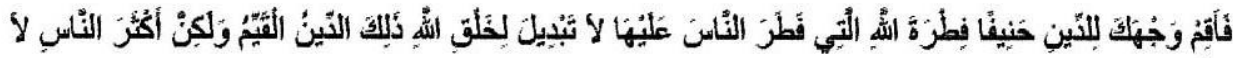

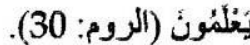

"Maka hadapkanlah wajahmu dengan Lurus kepada agama Allah; (tetaplah atas) fitrah Allah yang telah menciptakan manusia menurut fitrah itu. tidak ada perubahan pada fitrah Allah. (Itulah) agama yang lurus; tetapi kebanyakan manusia tidak mengetahui.

Rasulullah Saw juga mempertegas bahwa selain memiliki potensi fitrah, manusia juga memiliki potensi kesucian, yaitu bahwa manusia dilahirkan dalam keadaan suci. Sebagaimana Rasulullah Saw bersabda dari Abu Hurairah, sesungguhnya dia berkata: Rasulullah Saw bersabda: setup anak dilahirkan dalam keadaan suci, maka kedua orang tuanyalah yang menjadikan anak itu beragama Yahudi, Nasrani atau Majusi.

Mengapa MSDI penting? karena praktik kerja berkinerja tinggi, praktik yang menghasilkan kinerja individu dan organisasi yang tinggi, contoh: 1) Tim-tim kerja yang mengarahkan diri sendiri, 2) Rotasi jabatan,

${ }^{3}$ Melayu S.P, Hasibuan, Manajemen Sumber Daya Manusia (Jakarta, Bumi Aksara, 2003). 244. 
3) Pelatihan keterampilan yang tinggi tingkatannya, 4) Kelompok-kelompok pemecah masalah, 5) Proses dan prosedur manajemen mutu dan terpadu (total quality management), 6) Mendorong perilaku yang inovatif dan kreatif, 7) Keterlibatan dan pelatihan karyawan secara luas, 8) Pelaksanaan saran-saran karyawan, 9) Upah berubah-ubah berdasarkan perubahan kinerja, 10) Pelatihan dan pembinaan, 11) Banyak sekali berbagi informasi, 12) Menggunakan survei sikap karyawan, 13) Integrasi limas fungsi, 14) Prosedur perekrutan dan seleksi karyawan yang menyeluruh.

Prosedur MSDI adalah berbagai kegiatan yang diperlukan untuk mengisi staf dan mempertahankan karyawan yang bekerja tinggi. Seluruh proses MSDI itu dipengaruhi oleh lingkungan ekstemal. Kita telah memerinci kendala-kendala yang ditimbulkan oleh lingkungan terhadap para manajer. Faktor yang langsung mempengaruhi proses MSDI adalah serikat buruh dan peraturan perundang-undangan pemerintah.

Perencanaan sumber daya insani adalah proses yang dilakukan para manajer untuk menjamin ijahwa mereka memiliki jumlah dan jenis orang yang tepat, yang mampu menyelesaikan sejumlah tugas yang dibebankan secara efektif dan efisien. Jaminan tersebut meliputi antara lain :

1. Penilaian sekarang

a. Analisis pekerjaan adalah penilaian yang mendefenisikan berbagai pekerjaan dan perilaku yang perlu untuk melaksanakan pekerjaan tersebut.

b. Deskripsi pekerjaan atau deskripsi jabatan pernyataan tertulis mengenai apa yang harus diker akan pemegang jabatan, bagaimana cara mengerjakan, dan mengapa pekerjaan itu dikerjakan.

c. Spesifikasi jabatan adalah pernyataan kualifikasi minimum yang harus dimiliki seseorang untuk menjalankan pekerjaan tertentu secara berhasil.

2. Memenuhi kebutuhan sumber daya insani dimasa depan.

Kebutuhan akan sumber daya insani dimasa depan ditentukan oleh sasaran dan strategi organisasi. Permintaan akan karyawan merupakan hasil Bari permintaan akan jasa atau produk organisasi itu. Perekrutan dan pengangguran

3. Perekrutan adalah proses mencari, mengidentifikasi, dan menarik para calon yang berkemampuan. Pengurangan (decruitment) adalah sejumlah teknik untuk mengurangi pasokan tenaga kerja didalam organisasi. Seleksi adalah proses penyaringan pelamar kerja untuk memastikan bahwa kandidat yang paling layak yang akan dipekerjakan.

4. Keabsahan dan keandalan

Pandangan validitas hubungan yang dapat dibuktikan yang muncul 
antara perangkat seleksi dan sejumlah criteria kerja yang relevan. Keandalan adalah kemampuan perangkat seleksi mengukur hal yang sama secara konsisten.

5. Jenis alat seleksi

Rekrutmen tenaga kerja/recruitment. Rekrutmen adalah suatu proses untuk mencari calon atau kandidat pegawai, karyawan, buruh, manajer, atau tenaga kerja baru untuk memenuhi kebutuhan sumber daya insani oraganisasi atau perusahaan. Dalam tahapan ini diperlukan analisis jabatan yang ada untuk membuat deskripsi pekerjaan/job description dan juga spesifikasi pekerjaan/job specification.

Seleksi tenaga kerjalselection adalah suatu proses mendapatkan tenaga kerja yang tepat dari sekian banyak kandidat atau calon yang ada. Tahap awal yang perlu dilakukan kan setelah menerima berkas lamaran adalah melihat daftar riwayat hidup (curriculum vittae) milik pelamar. Kemudian dari curriculum vittae pelamar dilakukan penyortiran antara pelamar yang akan dipanggil dengan yang gagal memenuhi standar suatu pekerjaan. Lalu berikutnya adalah memanggil kandidat terpilih untuk dilakukan ujian test tertulis, wawancara kelalinterview dan proses seleksi lainnya. Jervis alas seleksi antara lain: 1) formulir lamaran, 2) ujian tertulis, 3) ujian simulasi kinerja, 4) wawancara, 5) penyelidikan latar, 6) pemeriksaan jasmani.

Dalam memahami berbagai permasalahan pada Manajemen Sumber Daya Insani dan sekaligus menentukan cara pemecahannya perlu diketahui terlebih dahulu model-model yang digunakan oleh perusahaan kecil tidak bias menerapkan model yang biasa digunakan oleh perusahaan besar. Demikian pula sebaliknya. Dalam perkembangan model-model ini berkembang sesuai dengan situasi dan kondisi serta tuntutannya.

Untuk menyusun berbagai aktifitas manajemen sumber daya insani ada 6 (enam) model yang digunakan, yaitu :

1. Model klerikal

Dalam model ini fungsi departemen sumber daya insani yang terutama adalah memperoleh dan memelihara laporan, data, catatancatatan dan melaksanakan tugas-tugas rutin. Fungsi departemen Sumber Daya Insani menangani kertas kerja yang dibutuhkan, memenuhi berbagai peraturan dan melaksanakan tugas-tugas kepegawaian rutin.

2. Model hukum

Dalam model ini, operasi sumber daya insani memperoleh kekuatannya dari keahlian di bidang hukum. Aspek hukum memiliki sejarah panjang yang berawal dari hubungan perburuhan, di masa negosiasi kontrak, pengawasan dan loyalitas merupakan fungsi pokok 
disebabkan adanya hubungan yang sering bertentangan antara manajer dengan karyawan.

3. Model finansial

Aspek finansial MSDI belakangan ini semakin berkembang karena para manajer semakin sadar akan pengaruh yang besar dari Sumber Daya Insani ini meliputi biaya kompensasi tidak langsung seperti biaya asuransi kesehatan, pensiun, asuransi jiwa, liburan dan sebagainya, kebutuhan akan keahlian dalam mengelola bidang yang semakin komplek, merupakan penyebab utama mengapa para manajer sumber daya insani.

4. Model Manajerial

Model manajerial memiliki dua versi yaitu versi pertama Manajer sumber daya insani memahami kerangka acuan kerja manajer lini yang berorientasi pada produktivitas. Versi kedua manajer melaksanakan beberpa fungsi Sumber Daya Insani. Departemen Sumber Daya Insani melatih Manajer dalam keahlian yang diperlukan untuk menangani fungsi-fungsi kunci Sumber Daya Insani seperti peningkatan evaluasi kinerja dan pengembangan. Karena karyawan pada umumnya lebih senang berinteraksi dengan manajer mereka sendiri dibanding dengan pegawai staf, maka beberapa departemen Sumber Daya Insani dapat menunjukan Manajer lini untuk berperan sebagai pelatih dan fasilitator.

5. Model Humanistik

Ide sentral dalam model ini adalah bahwa, Departemen yang mengatur sumber daya insani dibentuk untuk mengembangkan dan membantu perkembangan nilai dan potensi Sumber Daya Insani di dalam organisasi. Spesialis Sumber Daya Insani harus memahami individu karyawan dan membantunya memaksimalkan pengembangan diri dan peningkatan karir. Model ini menggambarkan tumbuhnya perhatian organisasi terhadap pelatihan dan pengembangan karyawan mereka.

6. Model Ilmu Perilaku

Model ini menganggap bahwa, ilmu perilaku seperti psikologi dan perilaku organis erupakan dasar aktivitas sumber daya insani. Prinsipnya adalah sebuah pendekatan sains terhadap perilaku manusia dapat diterapkan pada hampir semua permasalahan sumber daya insani bidang Sumber Daya Insani yang didasarkan pada prinsip sains meliputi teknik umpan batik, evaluasi, desain program dan tujuan pelatihan serta manajemen karir.

Ulasan pekerjaan yang realistis adalah ulasan mengenai suatu pekerjaan yang memberikan informasi yang positif dan juga yang 
negative tentang pekerjaan dan-perusahaan bersangkutan, antara lain :

a. Orientasi adalah pekerjaan karyawan baru dengan pekerjaan dan organisasinya.

b. Pelatihan karyawan adalah kegiatan manajemen Sumber Daya Insani yang punting yang terdiri atas:

1) Jenis pelatihan

2) Metode pelatihan

Kualitas sumber daya insani yang baik adalah manusia yang memiliki etos kerja, seperti yang telah dijabarkan oleh Faisal Badmen, antara lain sebagai berikut:

a. Tujuan manusia dalam melakukan pekerjaan adalah beribadah kepada Allah dan memakmurkan kehidupan dengan mengelola bumi beserta isinya. "Dan aku tidak menciptakan jin dan manusia melainkan supaya mereka mengabdi kepada-Ku. Aku tidak menghendaki rezki sedikitpun dari mereka dan aku tidak menghendaki supaya mereka memberi-Ku makan."

b. Kerja adalah usaha untuk mewujudkan keseimbangan antara pemenuhan kebutuhan jiwa dan jasmani. Dan carilah pada apa yang telah dianugerahkan Allah kepadamu (kebahagiaan) negeri akhirat, dan janganlah kamu melupakan bahagianmu dari (kenikmatan) duniawi dan berbuat baiklah (kepada orang lain) sebagaimana Allah telah berbuat baik, kepadamu, dan janganlah kamu berbuat kerusakan di (muka) bumi. Sesungguhnya Allah tidak menyukai orang-orang yang berbuat kerusakan.

c. Bekerja keras untuk mendapatkan rezki disertai dengan tawakal dan takwa kepada Allah. Dialah yang menjadikan bumi itu mudah bagi kamu, Maka berjalanlah di segala penjurunya dan makanlah sebahagian dari rezki- Nya. dan hanya kepadaNya kamu (kembali setelah) dibangkitkan.

d. Usaha yang halal dan menghindari usaha yang karam. Katakanlah: "tidak sama yang buruk dengan yang baik, meskipun banyaknya yang buruk itu menarik hatimu. Maka bertakwalah kepada Allah hai orangorang berakal, agar kamu mendapat keberuntungan.

e. Keimanan bahwa seluruh materi di dunia ini hanya milik Allah, sedang manusia bertugas sebagai khalifah. Berimanlah kamu kepada Allah dan Rasul-Nya dan nafkahkanlah sebagian dari hartamu yang Allah telah menjadikan kamu menguasainya. Maka orang-orang yang beriman diantara kamu dan menafkahkan (sebagian) dari hartanyarnemperoleh pahala yang besar.

f. Jujur dan amanah. Bukanlah menghadapkan wajahmu ke arah timur dan barat itu suatu kebajikan, akan tetapi Sesungguhnya kebajikan itu 
ialah beriman kepada Allah, hari Kemudian, malaikat-malaikat, kitabkitab, nabi-nabi dan memberikan harta yang dicintainya kepada kerabatnya, anak-anak yatim, orangorang miskin, musafir (yang memerlukan pertolongan) dan orangorang yang meminta-minta; dan (memerdekakan) hamba sahaya, mendirikan shalat, dan menunaikan zakat; dan orang-orang yang menepati janjinya apabila ia berjanji, dan orang-orang yang sabar dalam kesempitan, penderitaan dan dalam peperangan mereka Itulah orang-orang yang benar (imannya); dan mereka Itulah orang-orang yang bertakwa:

Strategi pengembangan sumber daya insani yang dilakukan oleh Nabi Muhammad Saw meliputi: 1) merencanakan dan menarik sumber daya insani yang berkualitas, 2) mengembangkan sumber daya insani agar berkualitas, 3) menilai kinerja sumber daya insani, 4) memberikan motivasi, dan 5) memelihara sumber daya yang berkualitas. ${ }^{4}$

Sejalan dengan langkah yang diambil Nabi Muhammad tersebut, Mujamil Qomar mengungkapkan bahwa MSDI mencakup tujuh komponen, yaitu: 1) perencanaan pegawai, (2) pengadaan pegawai, 3) pembinaan dan pengembangan pegawai, 4) promosi dan mutasi, 5) pemberhentian pegawai, 6) kompensasi, dan (7) penilaian pegawai. ${ }^{5}$

Komponen MSDI tersebut merupakan proses yang dilakukan suatu lembaga agar memperoleh sumber daya insani yang unggul dan mampu mengemban tanggung jawab sesuai keahliannya.

\section{Insentif}

Insentif sebagai sarana motivasi yang mendorong para pegawai untuk bekerja dengan kemampuan yang optimal, yang dimaksudkan sebagai pendapatan ekstra di luar gaji atau upah yang telah ditentukan. Pemberian insentif dimaksudkan agar dapat memenuhi kebutuhan para pegawai dan keluarga mereka. Istilah sistem insentif pada umumnya digunakan untuk menggambarkan rencana-rencana pembayaran upah yang dikaitkan secara langsung atau tidak langsung dengan berbagai standar kinerja pegawai atau profitabilitas organisasi.

Insentif dapat dirumuskan sebagai balas jasa yang memadai kepada pegawai yang prestasinya melebihi standar yang telah ditetapkan. Insentif merupakan suatu faktor pendofong bagi pegawai untuk bekerja lebih baik agar kinerja pegawai dapat meningkat.

Dari pengertian di atas untuk lebih jelas tentang insentif, di bawah

4 M. Suyanto Muhammad, Bussiness Strategy \& Ethics: Etika dan Strategi Bussiness Nabi Muhammad SAW, (Yogyakarta : Andi Offset 2008). 223.

5 Mujamil Qomar, Manajemen Pendidikan Islam, Strategi Baru Pengelolaan Lembaga Pendidikan Islam, (Jakarta: Erlangga, 2009). 137. 
ini ada beberapa ahli manajemen mengemukakan pengertian mengenai insentif. Insentif adalah tambahan balas jasa yang diberikan kepada karyawan tertentu yang prestasinya di atas prestasi standar. Insentif ini merupakan alat yang di pergunakan pendukung prinsip adil dalam pemberian kompensasi. ${ }^{6}$

Insentif merupakan imbalan langsung yang dibayarkan kepada karyawan karena prestasi melebihi standar yang ditentukan. Dengan mengasumsikan bahwa uang dapat mendorong karyawan bekerja lebih giat lagi, maka mereka yang produktif lebih menyukai gajinya dibayarkan berdasarkan hasil kerja. ${ }^{7}$ Atau pengertian lain insentif adalah suatu bentuk motivasi yang dinyatakan dalam bentuk uang atas dasar kinerja yang tinggi dan juga, merupakan rasa pengakuan dari pihak organisasi terhadap kinerja karyawan dan kontribusi terhadap organisasi perusahaan. ${ }^{8}$

Jadi menurut pendapat-pendapat para ahli di atas dapat disimpulkan, bahwa insentif adalah dorongan pada seseorang agar mau bekerja dengan baik dan agar lebih dapat mencapai tingkat kinerja yang lebih tinggi sehingga dapat menambah kemauan kerja dan motivasi seorang pegawai agar terciptanya suatu kinerja yang berkualitas sesuai dengan tujuan perusahaan.

Para manajer harus menyusun sistem insentif yang mencerminkan sifat pekerjaan dan tempat kerja yang berubah-ubah supaya senantiasa mampu memotivasi karyawan. Insentif organisasi dapat mencakup banyak macam imbalan dan tunjangan yang berbeda-beda seperti upah dan gaji pokok, upah serta gaji tambahan, upah insentif, dan tunjangan serta jasa lainnya.

Salah satu alasan pentingnya pembayaran insentif karena adanya ketidaksesuaian tingkat kompensasi yang dibayarkan kepada eksekutif dengan pekerja lain. Program insentif adalah salah satu cara untuk memungkinkan seluruh pekerja merasakan bersama kemakmuran perusahaan. $^{9}$

Pengembangan karir adalah rentetan posisi yang dipegang seseorang selama hidupnya antara lain: 1) Keadaan zaman dulu, 2) Anda dan karier anda sekarang. Sedangkan hal-hal terkini dalam Manajemen Sumber Daya Insani antara lain : 1) Mengelola perampingan, 2) Pengelola keragaman

${ }^{6}$ Melayu S.P. Hasibuan, Op. Cit, 117.

7 Mutiara S. Panggabean. Manajemen Sumber Daya Manusia, (Jakarta, Ghalia Indonesia, 2002), 77.

${ }^{8}$ Anwar Prabu Mangkunegara, Manajemen Sumber Daya Manusia, (Bandung, Remaja Rosdakarya, 2002), 89.

${ }^{9}$ Vituizal Rivai, Manajemen Sumber Daya Manusia Untuk Lembaga dari Teori ke Praktek (Jakarta, Rajawali Press, 2004). 387. 
angkatan kerja, 3) Perekrutan, 4) Seleksi, 5) Orintasi dan pelatihan, 6) Keseimbangan kehidupan kerja.

Kompensasi sebagai apa yang diterima SDM sebagai tukaran atas kontribusinya kepada lembaga. ${ }^{10}$ Penentuan upah bagi para pegawai sebelum mereka mulai menjalankan pekerjaannya, telah dijelaskan dalam hadis Nabi Saw yang berbunyi: "Barangsiapa mempekerjakan seorang pekerja, tnaka hares disebutkan upahnya." Dalam hadis tersebut, Rasulullah memberikan petunjuk bahwa dengan memberikan informasi gaji yang akan diterima, diharapkan akan memberikan dorongan semangat bagi pegawai untuk memulai pekerjaan, dan memberikan rasa ketenangan. ${ }^{11}$ Upah ditentukan berdasarkan jenis pekerjaan. Hal ini merupakan asas pemberian upah sebagaimana ketentuan yang dinyatakan Allah dalam firman-Nya surat al-Ahqaf ayat 19:

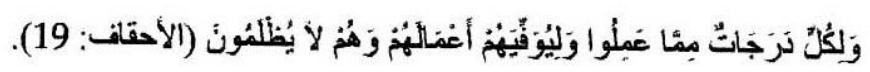

"Dan bagi masing-niasing mereka derajat menurut apa yang telah mereka kerjakan dan agar Allah mencukupkan bagi mereka (balasan) pekerjaan-pekerjaan mereka sedang mereka tiada dirugikan".

Selain itu, cara pemberian gaji kepada pegawai dalam Islam telah digariskan sesuai dengan sabda Nabi Saw: "berikan upah kepada pekerja sebelum keringatnya kering".

\section{KESIMPULAN}

Pada dasarnya setiap organisasi tidak akan lepas dari keberadaan Sumber Daya Insani yang dapat membantu melaksanakan serangkaizin aktivitas dalam pencapaian tujuan organisasi. Untuk itu diperlukan pula peran aktif manajer dalam memahami dan mengelola orang-orang yang ada dalam organisasi. Pengelolaan sumber daya insani harus dilakukan secara efektif dan efisien.

MSDI ini tidak saja mengandalkan pada fungsi manajemen seperti perencanaan, pengorganisasian, pengarahan dan pengendalian, namun pada implementasinya, mengandalkan pada fungsi operasional manajemen SDM seperti rekrutmen, seleksi, penilaian prestasi, pelatihan dan pengembangan, serta praktek pemberian kompensasi. Dari sisi pandangan agama Islam, hal ini juga tidak mengalami perbedaan. Semua praktek MSDI semuanya dijalankan dengan sebaik-baiknya, berdasarkan apa yang sudah ada dalam Al-Quran dan Al-Hadist.

${ }^{10}$ Wibowo, Manajemen Kinerja, (Jakarta, Rajawali, 2013), 348.

11 Ahmad Ibrahim Abu Siun, Manajemen Syariah: Sebuah Kajian Historis dan Kontemporer. Terjemahan Dimyauddin Djuwaini, (Jakarta, Raja Grafindo Persada, 2008), 113 . 


\section{DAFTAR PUSTAKA}

Ahmad Ibrahim Abu Siun, 2008, Manajemen Syariah: Sebuah Kajian Historis dan Kontemporer. Terjemahan Dimyauddin Djuwaini, Jakarta, Raja Grafindo Persada.

Anwar Prabu Mangkunegara, 2002, Manajemen Sumber Daya Manusia, Bandung, Remaja Rosdakarya.

Maman Rachman,1999, Strategi dan Langkah-langkah Penelitian. Semarang: IKIP Semarang Perss.

Melayu S.P, Hasibuan, 2003, Manajemen Sumber Daya Manusia, Jakarta, Bumi Aksara.

M. Suyanto Muhammad, 2008, Bussiness Strategy \& Ethics: Etika dan Strategi Bussiness Nabi Muhammad SAW, Yogyakarta : Andi Offset.

Mujamil Qomar, 2009, Manajemen Pendidikan Islam, Strategi Baru Pengelolaan Lembaga Pendidikan Islam, Jakarta: Erlangga.

Mutiara S. Panggabean. 2002, Manajemen Sumber Daya Manusia, Jakarta, Ghalia Indonesia.

Noeng Muhajir, 1983, Motede Penelitian Kualitatif, Edisi II, cet. Ke-8, Yogyakarta: Rake Sarasin.

Vituizal Rivai, 2004, Manajemen Sumber Daya Manusia Untuk Lembaga dari Teori ke Praktek, Jakarta, Rajawali Press.

Wibowo, 2013, Manajemen Kinerja, Jakarta, Rajawali. 